\title{
Passive immunization of macaques with polyclonal anti-SHIV lgG against a heterologous tier 2 SHIV: outcome depends on lgG dose
}

Anton M Sholukh 1,2,3, Siddappa N Byrareddy ${ }^{2,3,6 \dagger}$, Vivekanandan Shanmuganathan ${ }^{2+}{ }^{1}$, Girish Hemashettar ${ }^{2}$, Samir K Lakhashe 1,2,3, Robert A Rasmussen ${ }^{2,3}$, Jennifer D Watkins ${ }^{2,3}$, Hemant K Vyas ${ }^{1,2,3}$, Swati Thorat ${ }^{2,3}$, Tania Brandstoetter ${ }^{2}$, Muhammad M Mukhtar ${ }^{1,2,3}$, John K Yoon ${ }^{2}$, Francis J Novembre ${ }^{4,5}$, Francois Villinger ${ }^{4,6}$, Gary Landucci ${ }^{7}$, Donald N Forthal ${ }^{7}$, Sarah Ratcliffe ${ }^{8}$, Iskra Tuero ${ }^{9}$, Marjorie Robert-Guroff ${ }^{9}$, Victoria R Polonis ${ }^{10}$, Miroslawa Bilska ${ }^{11}$, David C Montefiori ${ }^{11}$, Welkin E Johnson ${ }^{12}$, Hildegund C Ertl ${ }^{13}$ and Ruth M Ruprecht ${ }^{1,2,3^{*}}$

\begin{abstract}
Background: A key goal for HIV-1 envelope immunogen design is the induction of cross-reactive neutralizing antibodies (nAbs). As AIDS vaccine recipients will not be exposed to strains exactly matching any immunogens due to multiple HIV-1 quasispecies circulating in the human population worldwide, heterologous SHIV challenges are essential for realistic vaccine efficacy testing in primates. We assessed whether polyclonal lgG, isolated from rhesus monkeys (RMs) with high-titer nAbs (termed SHIVIG), could protect RMs against the R5-tropic tier-2 SHIV-2873Nip, which was heterologous to the viruses or HIV-1 envelopes that had elicited SHIVIG.

Results: SHIVIG demonstrated binding to HIV Gag, Tat, and Env of different clades and competed with the broadly neutralizing antibodies b12, VRC01,4E10, and 17b. SHIVIG neutralized tier 1 and tier 2 viruses, including SHIV-2873Nip. NK-cell depletion decreased the neutralizing activity of SHIVIG 20-fold in PBMC assays. Although SHIVIG neutralized SHIV-2873Nip in vitro, this polyclonal IgG preparation failed to prevent acquisition after repeated intrarectal low-dose virus challenges, but at a dose of $400 \mathrm{mg} / \mathrm{kg}$, it significantly lowered peak viremia $(P=0.001)$. Unexpectedly, single-genome analysis revealed a higher number of transmitted variants at the low dose of $25 \mathrm{mg} / \mathrm{kg}$, implying increased acquisition at low SHIVIG levels. In vitro, SHIVIG demonstrated complement-mediated Ab-dependent enhancement of infection ( $\left.C^{\prime}-A D E\right)$ at concentrations similar to those observed in plasmas of RMs treated with $25 \mathrm{mg} / \mathrm{kg}$ of SHIVIG.
\end{abstract}

Conclusion: Our primate model data suggest a dual role for polyclonal anti-HIV-1 Abs depending on plasma levels upon virus encounter.

Keywords: Macaque model, Heterologous R5 SHIV clade C challenge, SHIVIG, Passive immunization, Enhancement of infection, Non-human primate model

\footnotetext{
*Correspondence: rruprecht@txbiomed.org

${ }^{\dagger}$ Equal contributors

${ }^{1}$ Department of Virology and Immunology, Texas Biomedical Research

Institute, PO Box 760549, San Antonio, TX 78245-0549, USA

²Dana-Farber Cancer Institute, Boston, MA, USA

Full list of author information is available at the end of the article
} reproduction in any medium, provided the original work is properly cited. The Creative Commons Public Domain Dedication waiver (http://creativecommons.org/publicdomain/zero/1.0/) applies to the data made available in this article, unless otherwise stated. 


\section{Background}

Although antibody (Ab)-mediated immunity against HIV-1 has been the focus of intense research, the role of Abs in preventing HIV-1 infection remains to be fully elucidated. The RV144 vaccine trial showed moderate efficacy (31.2\%) and raised the possibility that nonneutralizing Abs may be associated with protection against HIV-1 acquisition [1]. In this regard, a biologically relevant non-human primate model, in which macaques are passively immunized with Abs against simian-human immunodeficiency virus (SHIV) followed by repeated mucosal challenges with a heterologous R5 SHIV at low doses, may mimic key aspects of HIV-1 transmission among humans and thus play an important role in dissecting the mechanism(s) of $\mathrm{Ab}$ action in HIV-1 transmission and its prevention [2]. Another consideration in modeling natural infection in humans is the nature of transmitted HIV-1 strains: most such viruses are relatively difficult to neutralize (tier 2 neutralization phenotype).

Early attempts to use primates to elucidate the role of Abs were conducted with polyclonal IgG isolated from HIV-1-infected subjects (termed HIVIG) and showed either no or complete protection against laboratoryadapted, neutralization-sensitive (tier 1) viruses in chimpanzees depending on challenge virus doses [3-5]. Anti-HIV-1 envelope (Env) Abs have also been evaluated in rhesus monkeys (RMs) challenged with SHIVs encoding HIV-1 env, tat, rev and vpu. SHIVs allow assessing the protective role of broadly neutralizing anti-HIV-1 monoclonal Abs (bnmAbs) by passive immunization [reviewed in [2]]. Of note, SHIVs used earlier, such as SHIV $_{89.6 \mathrm{~B}}$, were either X4- or dual-tropic and irreversibly destroyed naïve and memory $\mathrm{CD}^{+} \mathrm{T}$ cells within two weeks [6]. When HIVIG alone or combined with bnmAbs was tested against $\mathrm{SHIV}_{89.6 \mathrm{PD}}[7,8]$, only the combination of HIVIG with bnmAbs resulted in moderate prevention of virus acquisition. In another pilot study, polyclonal IgG isolated from HIV-1-infected chimpanzees was administered to macaques that were challenged with homologous SHIV. Only two out of 10 macaques remained aviremic, one treated with highdose IgG and the other one challenged with a low dose of virus [9].

Early passive immunization studies in primates were performed with single high-dose, intravenous virus challenges rather than low-dose mucosal virus exposures that more closely resemble sexual HIV-1 transmission among humans. Recently, a passive immunization study using a combination of polyclonal IgG and bnmAbs was performed against repeated low-dose challenges with the tier 2 R5-tropic $\mathrm{SHIV}_{\mathrm{SF} 162 \mathrm{P} 3}$; virus acquisition could not be prevented even though the challenge virus was homologous to the polyclonal IgG given [10].
We have constructed SHIV-2873Nip, an R5-tropic SHIV carrying a HIV-1 clade C (HIV-C) env isolated from a Zambian infant who had rapid disease progression and died within 1 year of birth [11]. SHIV-2873Nip, a tier 2 virus, causes AIDS in RMs with clinical parameters and a disease progression rate similar to those in humans (unpublished data). Thus, the RM/SHIV$2873 \mathrm{Nip}$ model is a biologically relevant system to assess the role of Abs in providing protection against lentiviral acquisition.

Here we report passive immunization with SHIVIG, a polyclonal preparation of IgG isolated from RMs chronically infected with clade C SHIV strains carrying envelopes phylogenetically distinct from that of the challenge virus. We tested whether SHIVIG could protect RMs against multiple low-dose intrarectal (i.r.) challenges with SHIV-2873Nip that is heterologous to any viruses or envelopes against which the IgG responses had been elicited. We elected to perform upfront heterologous SHIV challenges to mimic the situation of human AIDS vaccine recipients, who are not likely to be exposed to HIV-1 strains that exactly match the composition of the immunogen(s). Thus, our passive immunization study in the primate model was designed to assess the level of cross-neutralizing IgG needed for in vivo protection; such information would be helpful to guide future development of Ab-based immunogens. Unexpectedly, virus acquisition was not prevented at any SHIVIG dose. Rather, we found evidence of partial inhibition of acute viremia or increased virus acquisition, depending on the SHIVIG dose.

\section{Results}

\section{Selection of RM donors and isolation of total lgG}

We selected RMs with high neutralizing antibody ( $\mathrm{nAb}$ ) titers against several viruses (Table 1). We had used these animals in previous virus adaptations, titrations, and vaccine studies [12-14]. All animals were chronically infected with SHIV-1157ip [12] and/or SHIV-1157ipd3N4 [15]; some monkeys had also been vaccinated (Additional file 1: Table S1) or challenged with Schistosoma mansoni, which the animals cleared after the acute stage of parasite infection [13]. Four RMs were long-term non-progressors. Some RMs developed Abs that neutralized heterologous viruses at high titers (Table 1). Sera collected sequentially from such SHIV-infected RMs were used to isolate total IgG; the final preparation was named SHIVIG (Methods).

\section{SHIVIG binding specificity and in vitro neutralization potency}

By ELISA, SHIVIG cross-recognized HIV-1 gp120 and gp140 of clades A, B and C, but did not bind to clade D Env. Anti-Gag binding activity was comparable to that against Env whereas level of Abs against HIV-1 Tat was 
Table 1 Neutralizing antibody titers of rhesus monkeys selected as SHIVIG donors

\begin{tabular}{|c|c|c|c|c|c|c|c|c|c|c|c|c|}
\hline \multirow[t]{2}{*}{ RM } & \multicolumn{2}{|c|}{ Homologous clade $\mathrm{C}$ viruses } & \multicolumn{6}{|c|}{ Heterologous clade $\mathrm{C}$ viruses } & \multicolumn{4}{|c|}{ Heterologous clade B viruses } \\
\hline & SHIV-1157ip (early, tier 1) & SHIV-1157ipd3N4 (late, tier 2) & $\mathrm{HIV}_{\mathrm{ZM} 135 \mathrm{M}}$ & $\mathrm{HIV}_{1084 \mathrm{i}}$ & HIV $_{\text {plndiec }}$ & $\mathrm{HIV}_{\text {ZM233M.PB6 }}$ & $\mathrm{HIV}_{\mathrm{ZM} 109 \mathrm{~F}}$ & SHIV-2873Nip & SHIV $_{\text {SF } 162 P 3}$ & $\mathrm{HIV}_{\mathrm{SF} 162 . \mathrm{LS}}$ & $\mathrm{HIV}_{\mathrm{NL4-3}}$ & $\mathrm{SHIV}_{89.6 \mathrm{P}}$ \\
\hline RAo-8 & 2,048 & $>640$ & $<20$ & & 128 & 42 & $<20$ & $>640$ & $<40$ & 220 & 32 & \\
\hline $\mathrm{RCt}-10$ & 360 & $>640$ & & & & & & $>640$ & & 6,500 & & \\
\hline RHo-10 & 250 & $>640$ & & & & & & $>640$ & & & & \\
\hline RHy -9 & 600 & $>10,240$ & $<20$ & 100 & 90 & $<20$ & $<20$ & $>640$ & & 173 & & 100 \\
\hline RJa-9 & 1,800 & $>10,240$ & $<20$ & & 128 & 59 & 22 & 2,048 & 68 & 35,770 & 128 & \\
\hline RLu-9 & $>1,280$ & $>640$ & $<20$ & 50 & 47 & $<20$ & $<20$ & $>640$ & & 58 & & 75 \\
\hline RMf-9 & 2,048 & $>640$ & $<20$ & & 128 & $<20$ & 35 & $>640$ & 78 & 18,303 & 128 & \\
\hline RPo-10 & 200 & $>640$ & & & & & & $>640$ & & & & \\
\hline RTs-7 & 2,048 & $>640$ & & & 128 & & & $>640$ & & & 32 & \\
\hline
\end{tabular}

NAb titers (reciprocal dilution of sera giving 50\% reduction in virus replication) were determined in TZM-bl cells or, for SHIV-1157ipd3N4 and SHIV-2873Nip, in human PBMC-based assays. The SHIVs were prepared in RM PBMC; HIV $_{1084 i} \mathrm{HIV}_{\mathrm{NL4} 43}$ and $\mathrm{HIV}_{\text {plndiec }}$ were prepared in human PBMC; nAb titers against the remaining HIV strains were performed using pseudoviruses generated in transfected $293 \mathrm{~T}$ cells. All neutralization assays were performed at least in duplicate. 
low (Figure 1A). Competition ELISA with bnmAbs b12, VRC01, 4E10 and 17b demonstrated the presence of Abs directed against the CD4-binding site, the CD4-inducible site and the membrane-proximal external region (MPER) of gp41, respectively (Figure 1B). Detailed analysis of antiEnv binding with consensus clade $\mathrm{C}$ gp120 peptides revealed Abs reacting with $\mathrm{V} 1$ and $\mathrm{V} 3$ and the $\mathrm{C} 5$ region (Figure 1C). Within gp41, SHIVIG interacted with the immunodominant region (IDR), the C-terminal heptad region $(\mathrm{CH})$, an undefined region between IDR and $\mathrm{CH}$ as well as with the intracellular portion. Thus, SHIVIG demonstrated antigen specificity similar to plasma samples from HIV-1-infected subjects [16].

Next, SHIVIG was tested for neutralization potency against tier 1 and tier 2 viruses (Table 2). While SHIVIG efficiently neutralized all three tier 1 viruses, neutralization of tier 2 strains was less potent: only two out of seven such viruses tested, including SHIV-2873Nip, were neutralized at
$60 \%$ efficiency. To establish the neutralization potency of SHIVIG against the intended heterologous challenge SHIV2873Nip in a more relevant assay, we performed human peripheral blood mononuclear cell (PBMC)-based assays with cells obtained from several donors. Neutralization of SHIV-2873Nip was as high as $95 \%$ ( $1 \mathrm{mg} / \mathrm{ml} \mathrm{SHIVIG).} \mathrm{The}$ half maximal inhibitory concentration $\left(\mathrm{IC}_{50}\right)$ values ranged from 0.2 to $144 \mu \mathrm{g} / \mathrm{ml}$ (mean, $11.9 \mu \mathrm{g} / \mathrm{ml}$ ) depending on the donor, a variability that is likely due to the inherent heterogeneity of PBMC from different donors, including natural killer (NK) cell receptor polymorphism [17].

\section{In vitro SHIVIG effector functions}

Increasing evidence suggests a role of NK cells in early antiviral defenses, including HIV-1 [18]. We performed PBMC-based neutralization assays with/without NK cells (Figure 2A). The virus/Ab mixture was left with the PBMC until day 4, thus allowing for ADCC activity.
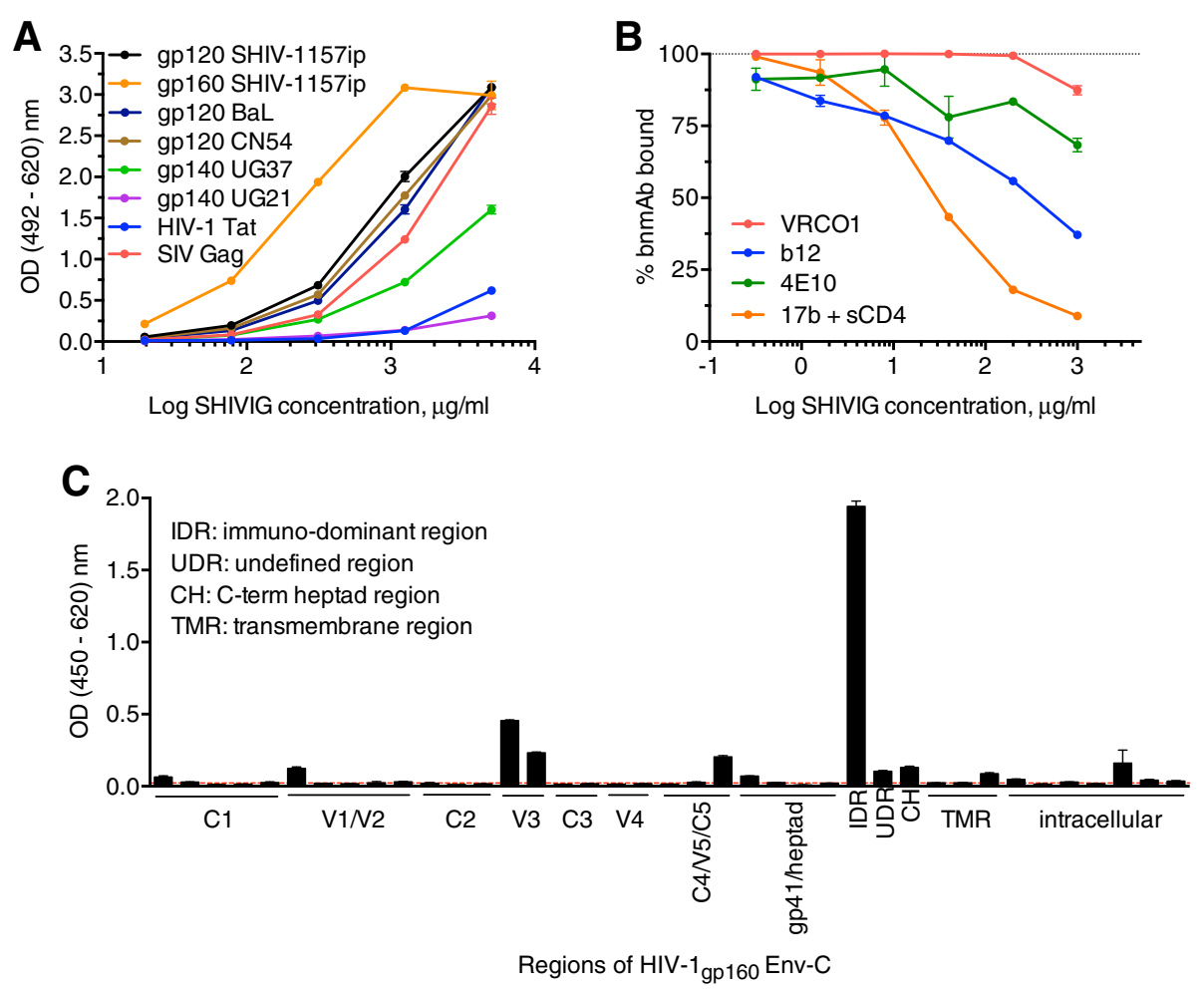

Figure 1 SHIVIG characterization. A. SHIVIG binding to soluble HIV and SIV proteins was tested by ELISA. Proteins were captured on the plates and probed with serial dilutions of SHIVIG. Binding was detected as described in Methods. Each data point represents the mean \pm SEM $(n=3)$. Env proteins were derived from the following HIV or SHIV strains: clade A, UG37; B, BaL; C, CN54 and SHIV-1157ip; D, UG21. B. Competitive ELISA with the CD4-binding site-specific bnmAbs b12 and VRC01; gp41 MPER-specific bnmAb 4E10; and CD4-inducible site-specific bnmAb 17b.

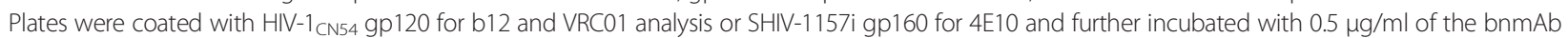

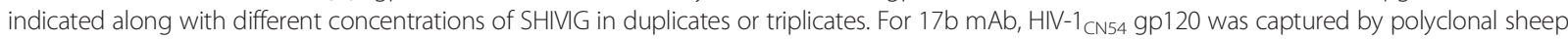
anti-gp120 Abs coated on the plate and the assay was continued as described in Methods. The $y$-axis indicates OD percentage of maximal binding, which is determined as the reading without SHIVIG (100\% binding is marked by dashed line). The irrelevant mAb Fm- 6 (anti-SARS virus) and naïve RM IgG were used as negative controls (not depicted). C. ELISA of SHIVIG with consensus clade C Env peptides. The $x$-axis designates pools of peptides assigned to HIV-1 Env regions. Dotted line represents background. IDR, immunodominant region; UDR, undefined region in gp41; CH, C-terminal heptad region; TMR, transmembrane region. Each data point represents the mean \pm SEM $(n=3)$. All experiments were repeated at least twice. 
Table 2 Percent neutralization of different virus strains by SHIVIG in TZM-bl cell-based assay

\begin{tabular}{lcccc}
\hline Virus & Clade & Tier & SHIVIG & bositive control \\
\hline KNH1088.ec5 & A & 2 & 0 & 83 \\
SF162 PV & B & 1 & 94 & 100 \\
BaL.ec1 & B & 1 & 92 & 99 \\
GS015.ec12 & C & 1 & 74 & 95 \\
GS 014 IMC & C & 2 & 0 & 82 \\
E0836M4.ec3 & D & 2 & 0 & 80 \\
CM235.ec5 & AE & 2 & 66 & 100 \\
GS 020 IMC & AE & 2 & 0 & 38 \\
55815.ec3 & AG & 2 & 0 & 75 \\
SHIV-2873Nip & C & 2 & ${ }^{a} 58$ & ${ }^{5} 56$
\end{tabular}

SHIVIG was tested at $0.5 \mathrm{mg} / \mathrm{ml}$, except where noted. ${ }^{\text {Neutralization obtained }}$ with $1 \mathrm{mg} / \mathrm{ml}$ of SHIVIG. ${ }^{\mathrm{b}} \mathrm{An}$ HIV-positive serum pool was used as positive control, except as indicated. 'BnmAb VRC01 $(50 \mu \mathrm{g} / \mathrm{ml})$ was used as positive control. IMC, infectious molecular clone. All neutralization assays were performed at least in duplicate.
NK-cell depletion led to a significant decrease of neutralization potency of SHIVIG, characterized by a 20 -fold increase of $\mathrm{IC}_{50}$ value from $2.2 \mu \mathrm{g} / \mathrm{ml}$ (PBMC) to $42 \mu \mathrm{g} / \mathrm{ml}$ (PBMC minus NK cells); virus neutralization by VRC01 was not affected.

SHIVIG almost completely inhibited the challenge virus at $0.2 \mathrm{mg} / \mathrm{ml}$ in the ADCVI assay performed with CEM.NKr.CCR5 target cells and human PBMC as effector cells (Figure 2B). To measure ADCC (Figure 2C), the same target cells were coated with clade $\mathrm{C} \mathrm{HIV}_{96 \mathrm{ZM} 651}$ gp120; PBMC were used as effector cells. We could not reach $>35 \%$ target cell killing, possibly due to imperfect recognition of the heterologous gp120 on the cell surface by SHIVIG.

\section{Animal study design and SHIVIG pharmacokinetics}

Next, we passively immunized RMs with three different doses of SHIVIG against weekly low-dose i.r. SHIV2873Nip challenges (Figure 3A). Group 1 RMs received SHIVIG at $400 \mathrm{mg} / \mathrm{kg}$, Group 2 at $675 \mathrm{mg} / \mathrm{kg}$, and Group 3 at $25 \mathrm{mg} / \mathrm{kg}$. Control Group 4 macaques were
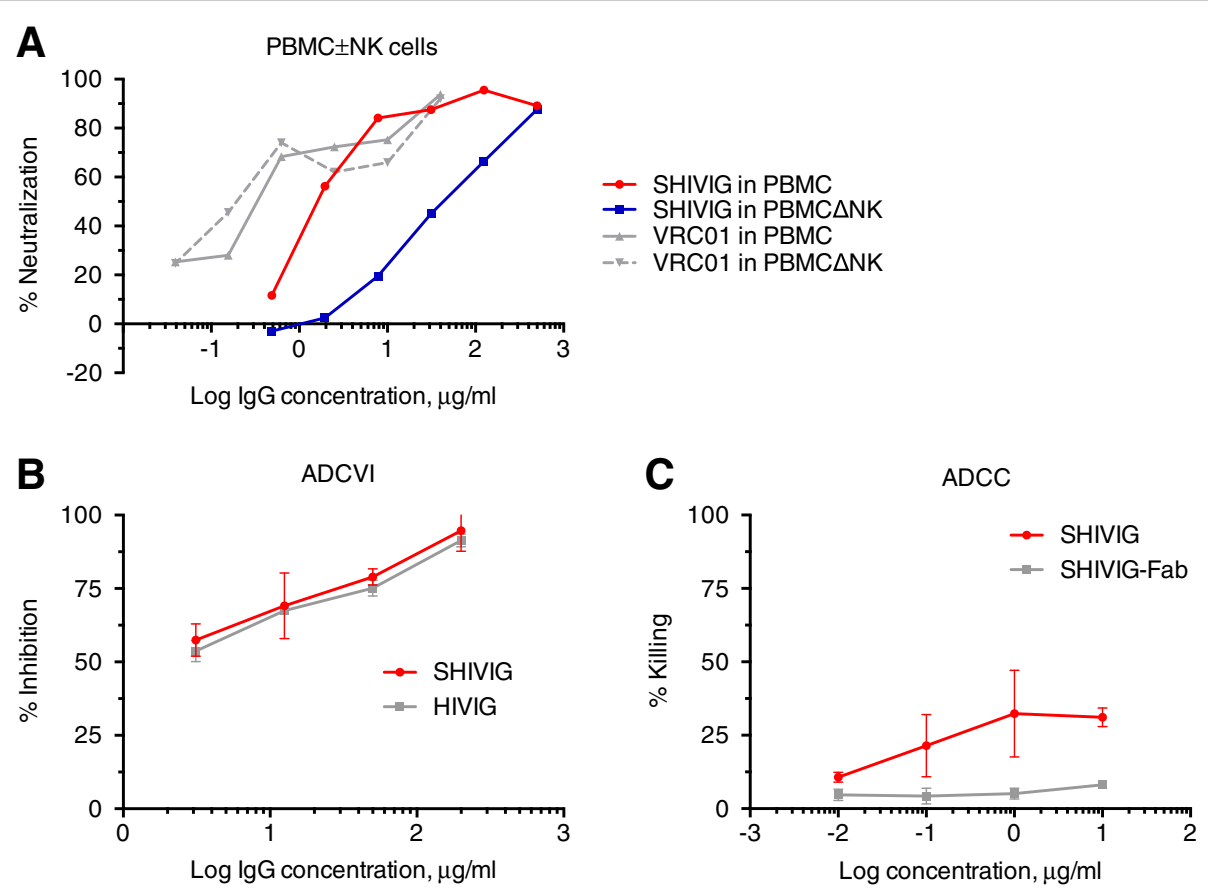

Figure 2 In vitro neutralization and effector functions of SHIVIG against the challenge virus, SHIV-2873Nip. A. Neutralizing activity of SHIVIG in PBMC assays with or without NK cells. Serially diluted SHIVIG was assayed with unfractionated human PBMC (red) and PBMC depleted of NK cells (blue) in triplicates. VRCO1 was used as a positive control and was analyzed with unfractionated human PBMC (solid grey line) and PBMC depleted of NK cells (dashed grey line) as described in Methods. B. ADCVI activity of SHIVIG and HIVIG (IgG from a pool of HIV-positive donors; positive control; squares) was assessed against SHIV-2873Nip as described in Methods. The graph shows the percentage of virus inhibition (y axis) by increasing concentrations of SHIVIG (red) or HIVIG (grey) normalized by values obtained for negative controls at the same concentrations. C. ADCC activity of serially diluted SHIVIG (red) and SHIVIG-derived Fab (grey) were tested in triplicates with CEM-NKr

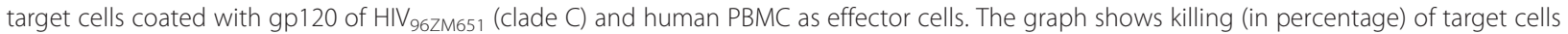
in the presence of increasing concentrations of SHIVIG or SHIVIG-Fab. Experiments were repeated in triplicate, and representative mean results are shown. 


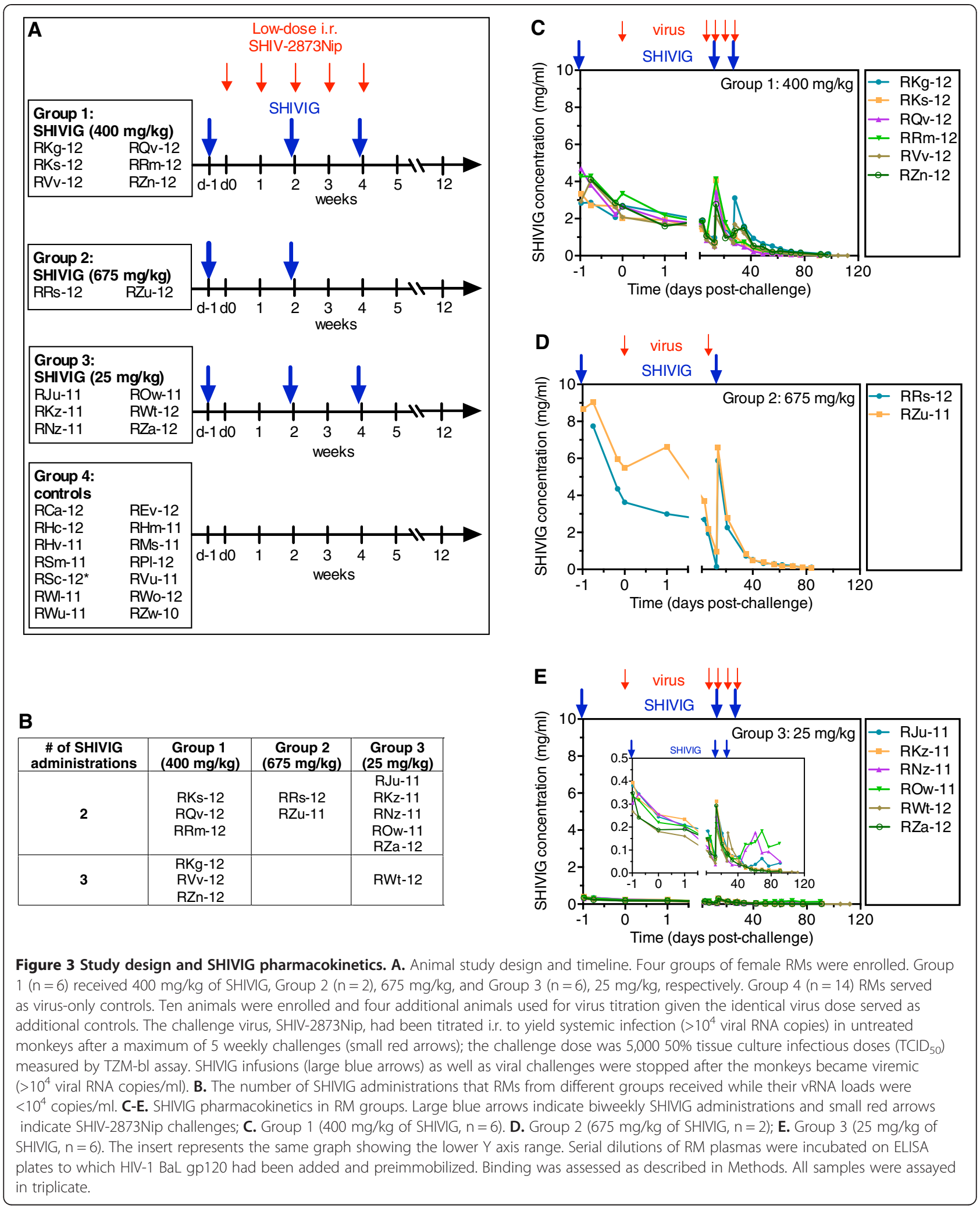


left untreated. Macaques with different MHC and TRIM $5 \alpha$ genotypes were distributed approximately evenly (Additional file 2: Table S2). SHIVIG was administered intravenously every two weeks, $24 \mathrm{~h}$ before the first, third and fifth low-dose viral challenges. A maximum of three SHIVIG administrations was given. All RMs were challenged i.r. weekly with low-dose SHIV-2873Nip (Figure 3A). SHIVIG infusions (Figure 3B) as well as viral challenges were stopped once an animal had $>10^{4}$ vRNA copies $/ \mathrm{ml}$, a level typically associated with subsequent seroconversion and hence persistent systemic infection.

SHIVIG plasma levels were measured by ELISA with gp120 as antigen (Figure 3C-E). SHIVIG had a biphasic decay with an initial drop during the first $24 \mathrm{~h}$ and a mean half-life of $12.2 \pm 1.8$ days after the last administration. These values are compatible with those observed by others for HIVIG and nAbs administered i.v. to RMs [7]. The mean SHIVIG concentration in RM plasma on the day of first viral challenge was $2.6 \pm 0.2 \mathrm{mg} / \mathrm{ml}$ for Group 1 (400 mg/kg), $4.6 \pm 0.9 \mathrm{mg} / \mathrm{ml}$ for Group $2(675 \mathrm{mg} / \mathrm{kg})$ and $0.22 \pm 0.01 \mathrm{mg} / \mathrm{ml}$ for Group $3(25 \mathrm{mg} / \mathrm{kg})$.

The penetration of SHIVIG into mucosal secretions was assessed by measuring anti-gp120 binding on day 13 in vaginal washes. The latter were collected because rectal mucosae could not be manipulated during i.r. virus challenges. In Group 1 RMs, SHIVIG represented $7.6 \pm$ $1.4 \%$ of total vaginal IgG (Table 3). SHIVIG concentration in mucosal secretions of Group $3(25 \mathrm{mg} / \mathrm{kg})$ was below the detection limit.

\section{SHIV-2873Nip challenges}

The repeated low-dose challenges resulted in infection of all passively immunized RMs (Figure 4A-D), although SHIVIG neutralized SHIV-2873Nip almost completely in vitro (Figure 2A). Mean time from initial virus exposure to peak viremia was $3.7 \pm 1.4$ weeks for Group 1, two weeks for Group 2, $3 \pm 1.6$ weeks for Group 3, and $2.7 \pm 0.9$ weeks for Group 4. These differences were not statistically significant.

Table 3 Percentage of SHIVIG in total vaginal IgG of Group 1 RMs two weeks after administration

\begin{tabular}{cc}
\hline Monkey & \% SHIVIG \\
\hline RKg-12 & 12.4 \\
RKs-12 & 5.2 \\
RQV-12 & 8.7 \\
RRm-12 & 4.3 \\
RVv-12 & 4.5 \\
RZn-12 & 10.4 \\
\hline
\end{tabular}

The content of SHIVIG and total RM IgG was determined as described in and Methods. All samples were analyzed in triplicates.

\section{Higher SHIVIG doses demonstrate partial protection}

We performed statistical analysis of parameters for viremia and found no significant differences in the time to viremia, time to peak viremia and area-under-thecurve (AUC) between different groups. However, Group 1 monkeys (400 mg/kg) demonstrated significantly lower peak viral RNA (vRNA) loads compared with control RMs $(P=0.001)$ (Figure 4E), indicating that SHIVIG administered at $400 \mathrm{mg} / \mathrm{kg}$ conferred significant partial protection against SHIV-2873Nip. Although the mean peak vRNA load of Group $3(675 \mathrm{mg} / \mathrm{kg})$ was lower compared with that of the control, statistical significance was not reached because we could only enroll two RMs. Statistical analyses did not reveal any correlation between viremia and MHC or TRIM5 $\alpha$ genotypes.

\section{All RMs seroconverted post challenge}

All macaques seroconverted by Western blot with HIV1/2 proteins and IgM ELISA with SIV Gag and HIV-1 Env as antigens (data not shown). IgM ELISAs were performed to distinguish between SHIVIG-associated titers that decline with time and $\mathrm{Ab}$ responses induced by breakthrough infection. Notably, three RMs from Group 3 (RNz-11, ROw-11, and RJu-11) developed rapid IgG responses after day 40 post-challenge and breakthrough infection (insert, Figure 3E). This observation agrees with recent reports [10] and indicates that a suboptimal concentration of virus-specific Abs in plasma at the time of virus challenge might facilitate the generation of humoral immune responses to the challenge virus.

\section{SHIV-2873Nip is not completely neutralized by plasma samples of passively immunized RMs}

Next, we assessed whether challenge virus neutralization by RM plasma after SHIVIG administration was comparable to in vitro assay values obtained for SHIVIG itself. Thus, we measured the neutralizing activity of RM plasma samples from the day of first virus challenge. All measurements were carried out using human PBMC obtained from the same individual. From every experimental group, we selected the animals with the highest and lowest viremia levels to test whether the differences could be linked to SHIVIG. $\mathrm{IC}_{50}$ values extrapolated from the plasma samples were consistent with $\mathrm{IC}_{50}$ values obtained earlier for the SHIVIG prep (Table 4). None of the plasma samples completely prevented PBMC infection. Furthermore, no significant differences were observed for $\mathrm{IC}_{50}$ values and percent neutralization for RMs with high versus low peak vRNA loads. Of note, plasma samples of Group 3 RMs demonstrated a lower percentage of SHIV2873Nip neutralization than those from animals of Groups 1 and 2. This suggests correlative trends between the administered dose of SHIVIG, neutralization, and partial protection against SHIV-2873Nip. 


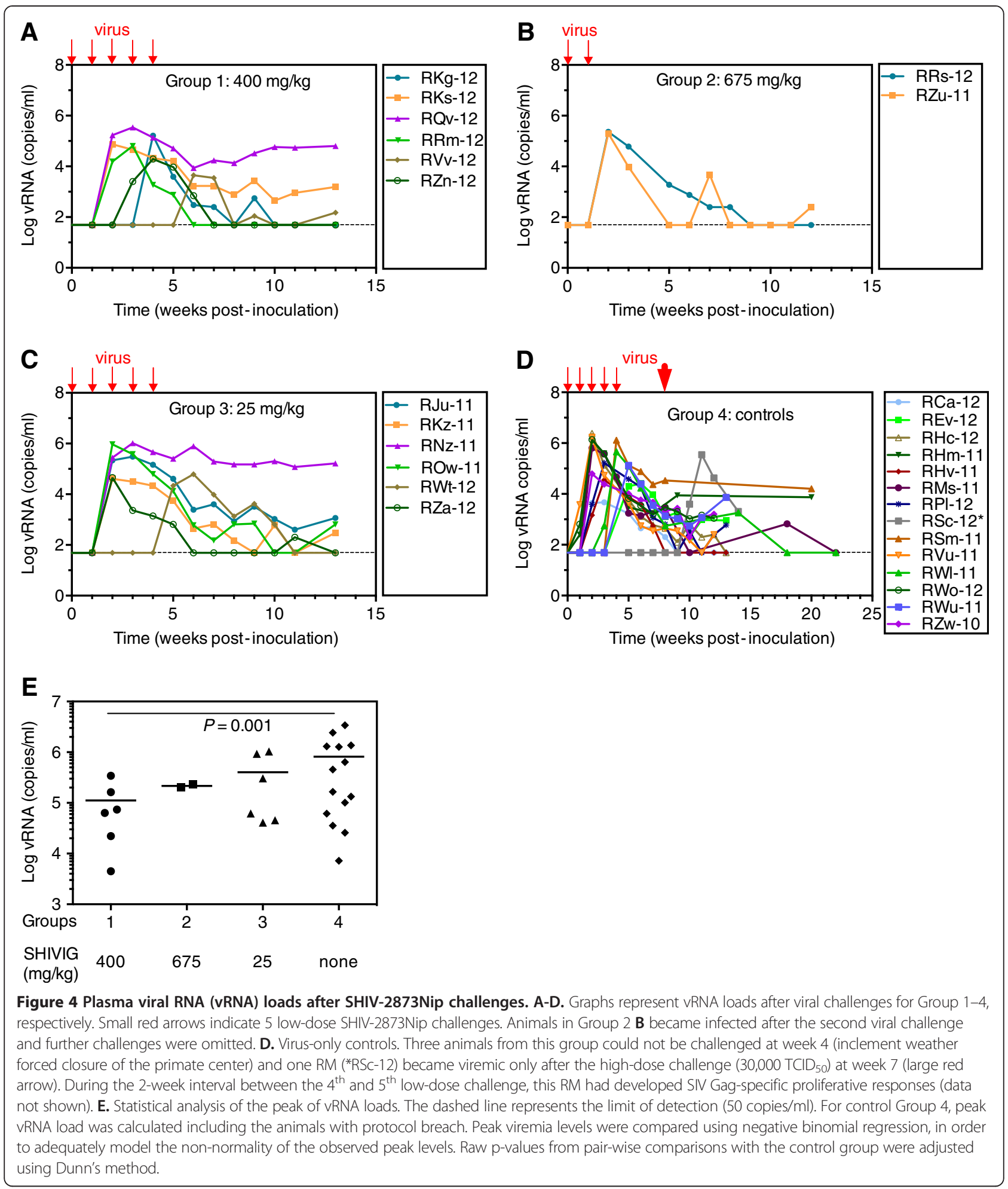

RMs treated with the low SHIVIG dose have more transmitted virus quasispecies

Next, we tested the number of transmitted virus variants (Figure 5A), using plasma samples collected at peak viremia. We amplified a $570 \mathrm{bp} e n v$ fragment spanning the V1/V2 region. For the final single-genome analysis (SGA), we obtained and sequenced $\geq 10$ individual clones per RM as well as 20 for the SHIV-2873Nip stock. Five quasispecies were observed in the virus stock, whereas control macaques demonstrated a median of two 
Table 4 Neutralization of SHIV-2873Nip by plasma samples of SHIVIG recipients

\begin{tabular}{|c|c|c|c|c|}
\hline \multirow{2}{*}{$\begin{array}{l}\text { Group } \\
\text { (mg/kg of SHIVIG) }\end{array}$} & \multirow[t]{2}{*}{ Monkey } & \multirow{2}{*}{$\begin{array}{c}\text { Peak } \\
\text { vRNA load (copies/ml) }\end{array}$} & \multicolumn{2}{|c|}{ Day of $1^{\text {st }}$ challenge } \\
\hline & & & Highest $\%$ of neutralization & SHIVIG plasma $\mathrm{IC}_{50}(\mu \mathrm{g} / \mathrm{ml})$ \\
\hline Group 1 & $R V V-12$ & 4,500 & 90.1 & 12.9 \\
\hline$(400)$ & RQv-12 & 342,850 & 85.7 & 10.9 \\
\hline Group 2 & RZu-11 & 201,700 & $74.7(91.8)$ & 6.0 \\
\hline (675) & RRs-12 & 229,600 & $88.8(95.6)$ & 4.8 \\
\hline Group 3 & RWt-12 & 61,750 & 58.5 & 6.2 \\
\hline (25) & RNz-11 & $1,032,600$ & 66.7 & 3.3 \\
\hline
\end{tabular}

The highest percent of neutralization was seen at a plasma dilution of 1:6. Values in parentheses represent the highest \% of neutralization reached for RZu-11 and RRs-11 at plasma dilutions 1:54 and 1:18, respectively. SHIVIG plasma $I_{50}$ concentrations were determined using the concentration of SHIVIG in RM plasma on the day of challenge and the dilution of the same plasma sample showing 50\% of neutralization in PBMC assay. Neutralization assays were performed at least in triplicate. Measurements of viral loads were performed in duplicate.

variants. The median number of quasispecies was 2.5 for Group $1(400 \mathrm{mg} / \mathrm{kg})$ and only one variant for Group 2 $(675 \mathrm{mg} / \mathrm{kg})$. In contrast, in Group 3 macaques $(25 \mathrm{mg} / \mathrm{kg})$, the number of variants ranged from two to six with a median of three variants, which was significantly different from the median number of quasispecies observed for the control group ( $P=0.032$ by Mann-Whitney test with Holm correction for multiple comparisons). These results imply increased virus acquisition at the low SHIVIG dose.

\section{SHIVIG at low concentration enhances virus infection in the presence of complement in vitro}

The surprise finding of an increased number of transmitted SHIV-2873Nip variants prompted us to postulate infection-enhancing activity resulting from low SHIVIG doses. To test this possibility, the SHIVIG preparation was tested for C'-ADE activity in the $\mathrm{CD} 21^{+}$SupT1.R5 cell line using two viruses containing envelopes closely related to the challenge virus, NL-LucR.2873Ni and NL-LucR.2873Nipd. NL-LucR.2873Ni bears the envelope
A
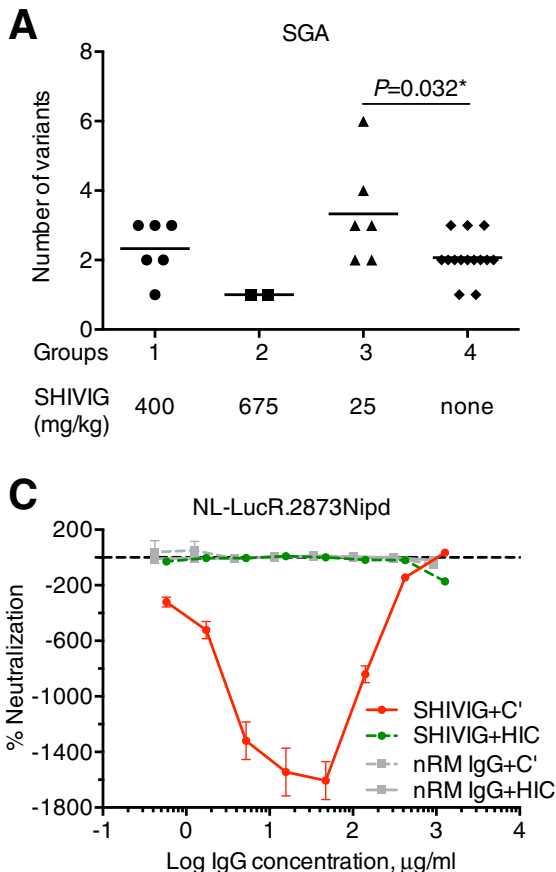
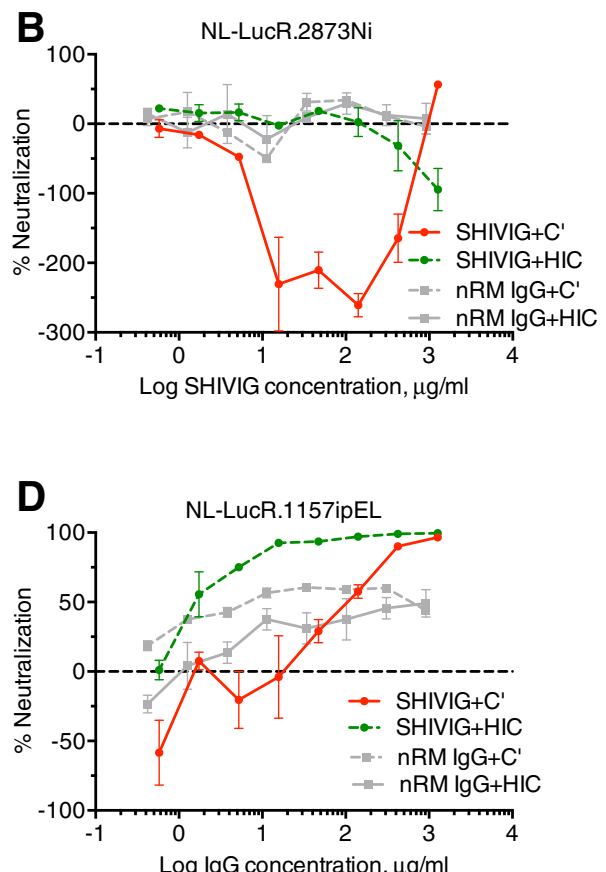

Figure 5 Single-genome analysis (SGA) and C'-ADE. A. Number of SHIV-2873Nip quasispecies at peak viremia. The number of quasispecies was analyzed by SGA of the V1/V2 loop region of SHIV-2873Nip env. For every RM, at least 10 individual clones were obtained by limiting dilution PCR followed by sequencing. Sequence readout was performed using both strands of DNA. Statistical significance was assessed by Mann-Whitney test with Holm correction $\left(P=0.032\right.$ ). B-D. $C^{\prime}-A D E$ activity of SHIVIG in SupT1.R5 cells tested against different viruses built from the HIV NL4-3 $_{3}$ backbone and containing the envelope of various SHIV or HIV-C strains as well as a Renilla luciferase (LuCR) reporter gene. B. NL-LuCR.2873Ni; C. NL-LuCR.2873Nipd; and D. NL-LucR.1157ipEL. SHIVIG (red solid and green dashed lines) or nRM IgG (grey solid and dashed lines) were assayed in presence of 10\% fresh (solid lines) or heat-inactivated (dashed lines) normal human serum as a source of complement. Each data point represents the mean \pm SEM $(n=3)$. All experiments were repeated at least twice. 
derived from SHIV-2873Ni, which is the parental virus used to obtain SHIV-2873Nip, the challenge virus, through passaging in RMs. NL-LucR.2873Nipd carries Env from SHIV-2873Nipd, which was isolated from an animal that developed AIDS and thus represents a late form of the same virus. SHIVIG enhanced infection of both viruses when fresh normal human serum was present as a source of complement (Figure 5B-C). Infection caused by "early" NL-LucR.2873Ni virus was enhanced by almost 3-fold, while infection by "late" NL-LucR.2873Nipd was augmented up to 16-fold. No significant enhancement was seen when the normal serum was heat-inactivated to destroy complement. Control IgG isolated from a naïve RM (nRM) did not show any enhancement effect. While SHIVIG at $1.27 \mathrm{mg} / \mathrm{ml}$ showed $50 \%$ neutralization of NL-LucR.2873Ni in the presence of fresh serum, NL-LucR.2873Nipd could not be neutralized. To control whether neutralization could be achieved in this assay, we tested the tier 1 NL-LucR.1157ipEL that carries an Env closely related to viruses against which SHIVIG had been raised (Additional file 1: Table S1). As shown in Figure 5D, SHIVIG completely neutralized the tier 1 NL-LucR.1157ipEL in the presence of either fresh or heat-inactivated complement. Two clade $C$ viruses (Ce1086 and Du151) from acute, sexually acquired infections and heterologous to challenge virus were also tested. SHIVIG enhanced the infection (up to 6-fold) of both viruses at lower concentrations and neutralized them at higher concentrations when fresh normal human serum was present as a source of complement (data not shown).

\section{Do SHIVIG concentrations yielding maximal C'-ADE in vitro correlate with SHIVIG plasma levels of Group 3 RMs given $25 \mathrm{mg} / \mathrm{kg}$ ?}

The C'-ADE data prompted us to compare SHIVIG concentrations that gave the highest degree of enhancement in the in vitro assay with SHIVIG plasma levels in Group 3 RMs. Among treated macaques, SHIVIG plasma concentrations on day 1 and day 8 after the administration varied between 180 to $250 \mu \mathrm{g} / \mathrm{ml}$ and $70-130 \mu \mathrm{g} / \mathrm{ml}$, respectively. The peak of enhancement of infection with NL-LucR.2873Ni in C'-ADE assay was observed in the same range of SHIVIG concentrations, 15.7 to $141 \mu \mathrm{g} / \mathrm{ml}$. This finding strongly suggests an association between the in vitro observed C'-ADE of infection and increased virus acquisition in vivo.

\section{Discussion}

Passive immunization with polyclonal SHIVIG given to RMs that were subsequently exposed repeatedly to low doses of the pathogenic R5 SHIV-2873Nip yielded partial protection at $400 \mathrm{mg} / \mathrm{kg}$ as evidenced by statistically significant lower peak viral RNA loads compared with control RMs. The SGA data suggest the possibility of increased viral acquisition at the low SHIVIG dose of $25 \mathrm{mg} / \mathrm{kg}$. When tested ex vivo in the presence of fresh complement, low SHIVIG concentrations showed significant $C^{\prime}$-ADE when tested with viruses carrying envelopes related to the challenge virus or other HIV-Cs. These results suggest the possibility that the polyclonal SHIVIG contained Abs with the ability to either partially protect or to facilitate virus acquisition.

These surprising data were generated in a primate model that sought to replicate as many aspects of HIV-1 transmission among humans as possible. Specifically, we chose to perform an upfront heterologous challenge, in contrast to earlier studies that matched the IgG preparation with the challenge virus Env $[9,10,19,20]$. We also elected to perform multiple low-dose challenges instead of using a single high-dose of virus. The low-dose challenge regimen resulted in a low number of transmitted viral variants in our control animals, a situation similar to that observed in humans. Lastly, the exclusive R5 tropism of our challenge virus reflects that of acutely transmitted founder viruses isolated from humans.

Ab-mediated enhancement of HIV-1 acquisition has been implicated in a recently published subgroup analysis of the Vax004 AIDS vaccine efficacy trial that involved gp120 immunogens [21]. This study linked Fcy receptor IIIa (FcyRIIIa) genotype with a significantly increased HIV-1 acquisition rate for vaccinees with low behavioral risk of infection and homozygosity for the FcyRIIIa V allele. Other evidence for in vivo increased viral acquisition following immunization stems from experiments involving SIV [22], feline immunodeficiency virus [23-25], and equine infectious anemia virus [26]. Enhancement of viral acquisition and/or higher viral loads or earlier viremia by pre-existing Abs are wellknown phenomena for dengue virus [27,28], Murray Valley encephalitis virus [29], respiratory syncytial virus [30], Ebola virus [31] and measles virus [32].

Another recent report described a passive immunization study conducted in HIV-infected pregnant women and their infants in Uganda with the aim of testing antiHIV-1 Ig (termed HIVIGLOB) for its ability to lower the risk of mother-to-infant virus transmission [33]. Two groups of pregnant women were enrolled; all mothers and their infants were treated with single-dose nevirapine (NVP) according to standard local protocol. Half of the women and their children also received HIVIGLOB (maternal dose, $200 \mathrm{mg} / \mathrm{kg}$ at week $36-38$ of gestation). The infants received HIVIGLOB at $400 \mathrm{mg} / \mathrm{kg}$ within $18 \mathrm{~h}$ of delivery. At birth, $9.1 \%$ of infants born to HIVIGLOB-treated mothers were HIV positive compared with $4.1 \%$ of control infants; the difference was statistically significant. The higher HIV-1 infection rate of HIVIGLOB-treated infants persisted throughout six months of follow-up, although differences at later time 
points were not statistically significant. In essence, passive immunization with HIVIGLOB did not prevent HIV-1 acquisition in any infants born to infected mothers, and may have enhanced in utero HIV-1 transmission.

Ab-mediated increased viral acquisition was also suggested in a recent study of Burton et al. [34], who performed passive immunization with human monoclonal Abs (mAbs), including the anti-CD4 binding site mAb b6, which is weakly neutralizing. The latter provided no protection from virus acquisition when tested against intravaginal challenge with $\mathrm{SHIV}_{\mathrm{SF} 162 \mathrm{P} 4}$ (tier 1) or SHIV $_{\text {SF162P3 }}$ (tier 2). SGA revealed a significantly higher number of newly transmitted quasispecies among the b6-treated monkeys compared with the control groups, which is compatible with increased virus acquisition.

Ab-mediated enhancement of lentiviral infection can occur through different mechanisms. The VAX004 data implied that increased risks of HIV-1 acquisition occurred through FcyR-mediated enhancement. Such a mechanism was first described by Takeda and Ennis [35]. Their studies involving cultured monocytes/ macrophages demonstrated IgG-linked enhancement of infection only in the presence of surface-expressed Fc-receptors (FcRs) and the IgG constant region. This enhancement still required virus entry through CD4, implying that FcR-bearing cells may enhance infectivity in trans. The second major mechanism was first described by Robinson et al., who demonstrated the critical role of complement in C'-ADE [36]. This activity was found to be highly prevalent in individuals with acute HIV-1 infection who had developed binding Abs but no autologous nAbs yet; strikingly, enhancement of infection reached levels up to 350-fold and was not only seen with autologous virus, but also with different virus isolates [37].

Prompted by our observation of an increased number of quasispecies seen in RMs given the low SHIVIG dose, we examined this preparation for C'-ADE activity in vitro. Significant enhancement of infection was seen at low SHIVIG concentrations, whereas higher concentrations of SHIVIG showed some virus-inhibitory activity, thus providing a potential mechanism for the increased number of quasispecies seen in the RMs treated with the low-dose SHIVIG. The complex interactions of HIV-1 with complement, including enhancement of infection, have been reviewed [38]. In this context, it is worth mentioning the recent suboptimal outcome of the phase IIb HVTN 505 trial [39]. The multicomponent immunogens contained envelope and possibly may have induced low levels of anti-Env Abs.

One of our initial goals for the passive immunization using the tier 2 SHIV-2873Nip had been to compare in vivo protection with in vitro neutralization titers of serum samples collected at the time of virus exposure. We now realize that the role of Abs directed against
HIV-1/SHIV is more complex in vivo and that the currently used neutralization assays have a narrow focus on prevention of virus entry. A more complex interaction of Abs and virus with primary cells is captured to a certain degree in PBMC-based assays but only if the Ab-virus mixture is left with the cells for several days, a protocol we have followed when assessing SHIVIG in vitro. In contrast, most neutralization assays include a washing step, in which the virus-Ab mixture is removed, thus not allowing ADCC activity to impact the final readout. Currently, routine neutralization assays do not query the influence of complement, and their lack of predictive value may be due to their oversimplified readout and lack of probing mechanisms that may influence the outcome in vivo.

To summarize, passive immunization with SHIVIG yielded partial protection at higher doses and may have increased viral acquisition at the low dose - a perplexing finding. Future studies are required to address the following questions: Can the Ab-mediated infectionenhancing activity be separated from protective functions, such as neutralization, ADCVI and ADCC? More important still, can immunogens be designed that will elicit protective but not infection-enhancing Abs? Will it be possible to induce durable $\mathrm{nAb}$ responses at sufficiently high levels to counteract any potential Ab-mediated enhancement of infection?

\section{Conclusions}

SHIVIG displayed the key characteristics of human Abs raised upon HIV-1 infection in humans. Passive immunization with SHIVIG yielded partial protection at higher doses and evidence of increased acquisition at the low dose. Our data imply that the polyclonal SHIVIG preparation contained Abs with the ability to either protect the host or to facilitate viral acquisition. These results were generated in a primate model that replicates as many aspects of HIV-1 transmission among humans as possible, including R5 tropism and a tier 2 neutralization phenotype of the challenge virus as well low-dose repeated mucosal challenges with heterologous virus.

\section{Methods \\ Animals}

RMs were housed at the Yerkes National Primate Research Center (YNPRC, Atlanta, GA) in accordance with standards of the National Institutes of Health Guide for the Care and Use of Laboratory Animals. Animal experiments were approved by the Institutional Animal Care and Use Committees at Emory University and the Dana-Farber Cancer Institute (DFCI) via a Collaborating Institution Animal Use Agreement. Blood was collected under ketamine or Telazol anesthesia. 


\section{Proteins and peptides}

HIV-1 Tat, HIV-1 ${ }_{\text {UG37 }}$ gp140 (clade A), HIV-1 $1_{\text {BaL }}$ gp120 and HIV-1 $1_{\text {IIIB }}$ gp120 (clade B), HIV-1 $1_{\mathrm{CN} 54}$ gp120 and HIV-1 ${ }_{96 Z M 651}$ gp120 (clade C) and HIV-1 ${ }_{\text {UG21 }}$ gp140 (clade D) along with consensus clade $\mathrm{C}$ peptides were kindly provided by the NIH AIDS Research and Reference Reagent Program. SHIV-1157ip gp120 and gp160 were kindly provided by Dr. S.-L. Hu. SIV Gag was from Immuno Diagnostics Inc.

\section{SHIVIG preparation}

Total IgG was isolated from sera of RMs infected with SHIV-1157ip [12], SHIV-1157ipd3N4 [15], or related viruses as published [10]. Heat-inactivated RM sera were diluted with PBS, IgG was isolated by chromatography (Protein G Sepharose, GE Healthcare) followed by buffer exchange to PBS, and concentrated by Amicon ultrafiltration (50 kDa cut-off membrane, Millipore). All IgG preparations from individual RMs were analyzed for neutralizing activity and then combined, concentrated to $26.2 \mathrm{mg} / \mathrm{ml}$, filter-sterilized and tested for the presence of endotoxin; all preparations contained $<0.02 \mathrm{EU}$ per $\mathrm{mg}$ of IgG.

\section{SHIVIG administration}

SHIVIG was administered intravenously every two weeks, $24 \mathrm{~h}$ before the first, third and fifth low-dose viral challenges. Group 1 RMs received SHIVIG at $400 \mathrm{mg} / \mathrm{kg}$, Group 2 at $675 \mathrm{mg} / \mathrm{kg}$, Group 3 at $25 \mathrm{mg} / \mathrm{kg}$, and control Group 4 macaques were left untreated. A maximum of three SHIVIG administrations was given. SHIVIG infusions were stopped once an animal had $>10^{4}$ vRNA copies $/ \mathrm{ml}$.

\section{ELISAs}

ELISA plates (Nunc) were coated with $1 \mu \mathrm{g} / \mathrm{ml}$ of HIV proteins in carbonate buffer, $\mathrm{pH}$ 9.6. After washing, plates were blocked with $2 \%$ BSA (Sigma-Aldrich), $0.05 \%$ TweenPBS (blocking buffer). Plates were then incubated with serial dilutions of SHIVIG in triplicates. After washing, plates were developed by incubation for $1 \mathrm{~h}$ with rabbit antimonkey IgG HRP-conjugated Ab (Sigma) and by adding $100 \mu \mathrm{l}$ of $o$-phenylenediamine solution.

For competitive ELISA with bnmAbs b12, VRC01 and 4E10, plates were coated with $0.1 \mu \mathrm{g} / \mathrm{ml}$ of $\mathrm{HIV}-1_{\mathrm{CN} 54}$ gp120. After washing and blocking with blocking buffer, plates were incubated with b12, VRC01 or $4 \mathrm{E} 10(0.5 \mu \mathrm{g} /$ $\mathrm{ml}$ ) along with different concentrations of SHIVIG in duplicates. After extensive washing, plates were incubated for $1 \mathrm{~h}$ with biotinylated goat anti-human IgG (RM IgG adsorbed; Southern Biotech) and $1 \mathrm{~h}$ with HRPstreptavidin (Jackson Immunoresearch). Plates were again washed, developed with 3,3',5,5'-tetramethylbenzidine solution (TMB; Invitrogen).

Competitive ELISA with mAb 17b was performed as described [40]. In brief, plates were coated with $1 \mu \mathrm{g} / \mathrm{ml}$ of sheep anti-gp120 Ab (Aalto Bio Reagents Ltd.) and blocked with blocking buffer. HIV-1 $1_{\mathrm{CN} 54}$ gp120 $(1 \mu \mathrm{g} / \mathrm{ml})$ was incubated with soluble CD4 $(40 \mu \mathrm{g} / \mathrm{ml})$ for $45 \mathrm{mi}-$ nutes. Then, mixture was diluted 20 -fold by blocking buffer, added to plates and incubated for $1.5 \mathrm{~h}$. After washing bnmAb $17 \mathrm{~b}(0.5 \mu \mathrm{g} / \mathrm{ml})$ along with different concentration of SHIVIG was added to the plate. Binding was detected as described above.

ELISA with consensus clade $\mathrm{C}$ peptides was performed essentially as described above. Plates were coated with pools of 5 peptides $(5 \mu \mathrm{g} / \mathrm{ml}$ for each) in triplicates, blocked and probed with $5 \mu \mathrm{g} / \mathrm{ml}$ of SHIVIG. To detect binding, plates were incubated with anti-monkey IgG $\mathrm{HRP}$-conjugated $\mathrm{Ab}$ and developed with TMB solution.

\section{Determination of SHIVIG and total IgG concentrations in RM samples}

The concentration of SHIVIG in plasma samples was determined by ELISA. The 96-well plates were coated with gp120 of HIV- $1_{\mathrm{BaL}}$ at $0.6 \mu \mathrm{g} / \mathrm{ml}$ for plasma SHIVIG determination and $1 \mu \mathrm{g} / \mathrm{ml}$ for measurement of SHIVIG content in vaginal lavages. Plates were incubated overnight at $4^{\circ} \mathrm{C}$. After blocking and washing, serially diluted, heatinactivated plasma samples were added to plates in triplicates. Vaginal lavage samples were thawed, diluted 1:1 with blocking buffer, heat-inactivated and added to plates in triplicate. SHIVIG was included as a standard ranging from 0.156 to $1 \mu \mathrm{g} / \mathrm{ml}$. To detect binding, plates were incubated with rabbit anti-monkey IgG HRP-conjugated $\mathrm{Ab}$ and developed with One Step Ultra TMB Substrate (Thermo Fisher Scientific). To determine the half-life of SHIVIG, natural logs of SHIVIG plasma levels were plotted as a function of time from the end of infusion. Slopes of the linear graphs were determined by least-squares analysis. Half-lives were calculated as $t_{1 / 2}=-(\ln 2) / \mathrm{m}$.

Total IgG content in vaginal lavage fluids was assessed by ELISA. Briefly, plates were coated with rabbit anti-monkey IgG-whole molecule (Sigma), blocked and probed with serially diluted vaginal lavage samples in triplicates. After washing, bound IgG was detected with rabbit anti-monkey IgG HRP-conjugated $\mathrm{Ab}$ and developed with One Step Ultra TMB Substrate. Naïve RM (nRM) IgG served as a standard.

\section{In vitro neutralization assays}

The TZM-bl assay was performed as described [41]. In brief, virus was added to cells in the presence of DEAEdextran (Sigma), washed $1 \times$ on day 1 and luminescence was measured on day 2 using luciferase substrate BrightGlo (Promega).

Human PBMC-based assay was performed as described [42]. Serially diluted SHIVIG was incubated with virus for $1 \mathrm{~h}$ at $37^{\circ} \mathrm{C}$. The virus/SHIVIG mixture was then added to the cells. Supernatant aliquots were harvested 
every other day starting on day 3. To remove anti-Gag antibodies that could interfere with the p27 assay readout, plates were washed 5 times on day 4 . The levels of p27 in supernatants were assayed first in wells containing only cells plus virus. When p27 levels were in the linear phase of increase in these control wells, neutralization was assessed for test samples. To analyze the role of NK cells, the same PBMC assay was run with and without NK cells from the same donor. PBMC were depleted of NK cells using an anti-CD56 mAb linked to magnetic beads according to the manufacturer's protocol (Stemcell Technologies).

Ab-dependent cell-mediated viral inhibition ( $A D C V I)$ assay IgG ADCVI activity was measured as described [43]. Briefly, SHIV-2873Nip-infected CEM.NKr.CCR5 target cells were incubated with SHIVIG or HIVIG (IgG from a pool of HIV-positive donors) and with fresh PBMC effector cells from normal human donors (effectorto-target cell [E:T] ratio of 10:1). Cells were washed to remove $\mathrm{Ab}$ on day 4 . On day 7 , supernatants were assayed for p27 by ELISA. IgG from naïve RM and IVIG (IgG from a pool of healthy donors) were used as negative controls. Percent virus inhibition was calculated with regards to the value obtained with the negative control used at the same concentration as described [43]. All samples were assayed in triplicates.

\section{Ab-dependent cell-mediated cytotoxicity (ADCC) assay}

Measurement of ADCC activity was performed as described [44]. Briefly, target CEM-NKr cells were coated

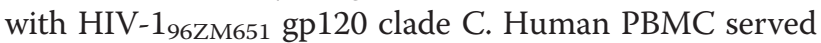
as effectors and were used at an effector to target (E:T) ratio of 50:1. ADCC titers are defined as the reciprocal dilution at which the \% killing was greater than the mean \% killing of the negative controls plus three standard deviations. SHIVIG-derived Fab-fragments were used as a negative control.

\section{Complement-mediated Ab-dependent enhancement (C'-ADE) assay}

Viruses used were all clade C. Env genes from SHIV2873Ni, SHIV-2873Nipd and SHIV-1157ipEL were cloned into the pNL-LucR.T2A vector containing Renilla luciferase gene inserted into pNL4-3 DNA [45]. Virus stocks were produced in $293 \mathrm{~T}$ cells (NL-LucR-2873Ni, NL-LucR2873Nipd and NL-LucR-1157ipEL) or human PBMC (HIV-C strains Ce1086 and Du151). C'-ADE of virus infection was measured in SupT1.R5 cells as described [37]. Virus was incubated with serial dilutions of SHIVIG or nRM IgG in duplicates in the presence of $10 \%$ fresh human serum as source of complement (Sigma) for $1 \mathrm{~h}$ at $37^{\circ} \mathrm{C}$. As control, SHIVIG was also assayed in the presence of $10 \%$ human serum heat-inactivated $\left(56^{\circ} \mathrm{C}, 1 \mathrm{~h}\right)$ to destroy complement activity. Percent neutralization was determined by calculating the difference in average relative luminescence units (RLU) between test wells (cells + serum + virus) and cell control wells (cells only), dividing this result by the difference in average RLU between virus control (cell + virus) and cell-control wells, subtracting from 1 and multiplying by 100. Negative values are indicative of infection-enhancement.

\section{Single-genome analysis (SGA)}

The 570 base-pair env fragment spanning V1/V2 was amplified as described [46]. In brief, total RNA was extracted and purified from RM plasma using QIAamp viral RNA kit (Qiagen, Valencia, CA). Reverse transcription was performed using the Superscript III kit (Invitrogen, Carlsbad, CA) according to the manufacturer's instructions using SHIV-2873Nip env-specific primers. The cDNA was serially diluted and dispersed in 96-well plates to identify a dilution constituting $<30 \%$ of the total number of PCR-positive wells as described [47]. Nested PCR was performed on the cDNA to amplify the $570 \mathrm{bp}$ env fragment. The following primers were used; for the first round forward primer (F): 5' -ATGAGAGTGAAG GAGAAATATCAGCACTTTGTGGAGA-3' and reverse primer (R): 5' -TTCCTCATCTATATCATCCATATTTTG TTTTCTGTA-3'. For the second round F: 5' -GGTACCT GTGTGGAAAGAAGCAAAAACTACTCTAT-3' and R: 5'-GGCTACCATTTAACAATAGTTGAGTTGACACCA CT-3'. PCR conditions and reagents were used as described [46]. Correctly sized amplicons were identified by agarose gel electrophoresis and sequenced using env-specific primers. All sequences were quality checked, analyzed for diversity, viral recombination, PCR and sequencing errors as described [46]. Finally, phylogenetic trees were constructed and the number of variants was estimated.

\section{Statistical analysis}

Mean times to first or peak viremia as well as peak viremia levels were calculated for each SHIVIG group. Distribution assumptions of the outcomes were examined graphically and used to determine the appropriate models for statistical analyses. Generalized linear models were used to compare the outcomes between the control and SHIVIG-recipient groups assuming either a Poisson or negative binomial distribution, as appropriate, with log-transformation. Furthermore, the AUC was calculated for each animal, and group comparisons of log-transformed AUCs were conducted via one-way ANOVA. Adjustments for multiple comparisons were incorporated, as necessary. Additionally, secondary outcomes analyses were conducted within MHC and TRIM $5 \alpha$-resistant genotypes, as numbers allowed. All analyses were conducted using StataMP 11.0 (StataCorp LP, College Station, TX). 


\section{Additional files}

Additional file 1: Table S1. Treatment history and clinical parameters for cohort of RMs used to isolate SHIVIG.

Additional file 2: Table S2. Genetic characteristics of rhesus monkeys enrolled into the study.

\section{Abbreviations}

Ab: Antibody; mAb: monoclonal antibody; nAb: neutralizing antibody; bnmAb: broadly neutralizing monoclonal antibody; ADCC: Antibody-dependent cell-mediated cytotoxicity; ADCVI: Antibody-dependent cell-mediated virus inhibition; AUC: area-under-the-curve; C'-ADE: Complement-dependent antibody-mediated enhancement; Env: Envelope; FcR: Fc-receptor; HIV-C: HIV-1 clade C; MPER: Membrane-proximal external region; $\mathrm{IC}_{50}$ : Half maximal inhibitory concentration; i.r.: Intrarectal; RM: Rhesus monkey; SGA: Single-genome analysis; SHIV: Simian Human Immunodeficiency Virus; TCID $_{50}$ : 50\% tissue culture infectious dose.

\section{Competing interests}

The authors declare that they have no competing financial interest.

\section{Authors' contributions}

Contribution: A.M.S., R.A.R., H.C.E. and R.M.R conceived the study and designed the experiments; A.M.S., S N.B., V.S., G.H., S.K.L., J.D.W., H.K.V., S.T., T.B., M.M.M., and J.K.Y. performed the experiments; F.J.N and F.V. managed primate experiments; G.L. and D.N.F. performed ADCVI analysis; I.T. and M.R.-G. performed ADCC assay; V.R.P, M.B. and D.C.M. performed neutralization assay of SHIVIG and RM plasmas; S.R. performed statistical analysis; W.E.J performed TRIM5a genotyping; A.M.S. and R.M.R analyzed the data and wrote the manuscript. All authors read and approved the final manuscript.

\section{Acknowledgements}

We thank Dr. J. Mascola for providing mAb VRC01, Dr. S.-L. Hu for providing SHIV-1157ip Env proteins, Dr. W. Marasco for providing mAb Fm-6, Dr. C. Ochsenbauer for providing pNL-LucR.T2A plasmid, P. Ehrenberg for production of the infectious molecular clones (GS 014 and GS 020), Dr. J. Hoxie for providing SupT1.R5 cells, and Juan Esquivel for technical help with the manuscript. This work was supported by NIH grants P01 Al082282 to RMR, SR and HCE, R37 Al034266, R01 DE023049 and P01 Al048240 to RMR, R01 Al083118 to WEJ, and HHSN27201100016C to DCM as well as by a cooperative agreement (W81XWH-07-2-0067) between the Henry M. Jackson Foundation for the Advancement of Military Medicine, Inc., and the U.S. Department of Defense (DOD) to VRP. This project was also funded in part by the Intramural Research Program of the NIH, National Cancer Institute, to MR-G and by the Office of Research Infrastructure Programs/OD P51OD11107 to the YNPRC. The authors have no conflicting financial interests.

\section{Author details}

${ }^{1}$ Department of Virology and Immunology, Texas Biomedical Research Institute, PO Box 760549, San Antonio, TX 78245-0549, USA. ²Dana-Farber Cancer Institute, Boston, MA, USA. ${ }^{3}$ Harvard Medical School, Boston, MA, USA. ${ }^{4}$ Yerkes National Primate Research Center, Emory University, Atlanta, GA, USA. ${ }^{5}$ Department of Microbiology and Immunology and Laboratory Medicine, Emory University, Atlanta, GA, USA. ${ }^{6}$ Department of Pathology and Laboratory Medicine, Emory University, Atlanta, GA, USA. ${ }^{7}$ Division of Infectious Diseases, Department of Medicine, University of California, Irvine School of Medicine, Irvine, CA, USA. ${ }^{8}$ Department of Biostatistics and Epidemiology, Perelman School of Medicine, University of Pennsylvania, Philadelphia, PA, USA. ${ }^{9}$ National Cancer Institute, Center for Cancer Research, Vaccine Branch, Bethesda, MD, USA. ${ }^{10}$ The Military HIV Research Program, Walter Reed Army Institute of Research, Silver Spring, MD, USA.

${ }^{11}$ Department of Surgery, Duke University School of Medicine, Durham, NC, USA. ${ }^{12}$ Department of Biology, Boston College, Boston, MA, USA. ${ }^{13}$ The Wistar Institute, Philadelphia, Pennsylvania, USA.

Received: 24 September 2013 Accepted: 9 January 2014

Published: 20 January 2014

\section{References}

1. Haynes BF, Gilbert PB, McElrath MJ, Zolla-Pazner S, Tomaras GD, Alam SM, Evans DT, Montefiori DC, Karnasuta C, Sutthent R, et al: Immune-correlates analysis of an HIV-1 vaccine efficacy trial. N Engl J Med 2012 366:1275-1286.

2. Lakhashe SK, Silvestri G, Ruprecht RM: No acquisition: a new ambition for HIV vaccine development? Curr Opin Virol 2011, 1:246-253.

3. Prince AM, Horowitz B, Baker L, Shulman RW, Ralph H, Valinsky J, Cundell A, Brotman B, Boehle W, Rey F, et al: Failure of a human immunodeficiency virus (HIV) immune globulin to protect chimpanzees against experimental challenge with HIV. Proc Natl Acad Sci USA 1988, 85:6944-6948.

4. Prince AM, Reesink H, Pascual D, Horowitz B, Hewlett I, Murthy KK, Cobb KE, Eichberg JW: Prevention of HIV infection by passive immunization with HIV immunoglobulin. AIDS Res Hum Retroviruses 1991, 7:971-973.

5. Eichberg JW, Murthy KK, Ward RH, Prince AM: Prevention of HIV infection by passive immunization with HIVIG or CD4-IgG. AlDS Res Hum Retroviruses 1992, 8:1515.

6. Igarashi T, Brown CR, Endo Y, Buckler-White A, Plishka R, Bischofberger N, Hirsch V, Martin MA: Macrophage are the principal reservoir and sustain high virus loads in rhesus macaques after the depletion of CD4+ T cells by a highly pathogenic simian immunodeficiency virus/HIV type 1 chimera (SHIV): implications for HIV-1 infections of humans. Proc Natl Acad Sci USA 2001, 98:658-663.

7. Mascola JR, Lewis MG, Stiegler G, Harris D, VanCott TC, Hayes D, Louder MK, Brown CR, Sapan CV, Frankel SS, et al: Protection of macaques against pathogenic simian/human immunodeficiency virus 89.6PD by passive transfer of neutralizing antibodies. J Virol 1999, 73:4009-4018.

8. Mascola JR, Stiegler G, VanCott TC, Katinger H, Carpenter CB, Hanson CE, Beary $H$, Hayes D, Frankel SS, Birx DL, Lewis MG: Protection of macaques against vaginal transmission of a pathogenic HIV-1/SIV chimeric virus by passive infusion of neutralizing antibodies. Nat Med 2000, 6:207-210

9. Shibata R, Igarashi T, Haigwood N, Buckler-White A, Ogert R, Ross W, Willey R, Cho MW, MartinMalcolm A: Neutralizing antibody directed against the HIV-1 envelope glycoprotein can completely block HIV-1/SIV chimeric virus infections of macaque monkeys. Nat Med 1999, 5:204-210.

10. $\mathrm{Ng} C T$, Jaworski JP, Jayaraman $P$, Sutton WF, Delio $P$, Kuller $L$, Anderson D, Landucci G, Richardson BA, Burton DR, et al: Passive neutralizing antibody controls SHIV viremia and enhances $B$ cell responses in infant macaques. Nat Med 2010, 16:1117-1119.

11. Siddappa NB, Song R, Kramer VG, Chenine AL, Velu V, Ong H, Rasmussen RA Grisson RD, Wood C, Zhang H, et al: Neutralization-sensitive R5-tropic simian-human immunodeficiency virus SHIV-2873Nip, which carries env isolated from an infant with a recent HIV clade C infection. J Virol 2009, 83:1422-1432

12. Humbert $M$, Rasmussen $R A$, Song $R$, Ong $H$, Sharma $P$, Chenine $A L$, Kramer VG, Siddappa NB, Xu W, Else JG, et al: SHIV-1157i and passaged progeny viruses encoding R5 HIV-1 clade C env cause AIDS in rhesus monkeys. Retrovirology 2008, 5:94.

13. Ayash-Rashkovsky M, Chenine AL, Steele LN, Lee SJ, Song R, Ong $H_{\text {, }}$ Rasmussen RA, Hofmann-Lehmann R, Else JG, Augostini P, et al: Coinfection with Schistosoma mansoni reactivates viremia in rhesus macaques with chronic simian-human immunodeficiency virus clade $\mathrm{C}$ infection. Infect Immun 2007, 75:1751-1756.

14. Rasmussen RA, Ong H, Song R, Chenine AL, Ayash-Rashkovsky M, Hu SL, Polacino P, Else JG, Novembre FJ, Ruprecht RM: Efficacy of a multigenic protein vaccine containing multimeric HIV gp160 against heterologous SHIV clade C challenges. AIDS 2007, 21:1841-1848.

15. Song RJ, Chenine AL, Rasmussen RA, Ruprecht CR, Mirshahidi S, Grisson RD, Xu W, Whitney JB, Goins LM, Ong H, et al: Molecularly cloned SHIV1157ipd3N4: a highly replication- competent, mucosally transmissible R5 simian-human immunodeficiency virus encoding HIV clade C Env. J Virol 2006, 80:8729-8738.

16. Binley JM, Lybarger EA, Crooks ET, Seaman MS, Gray E, Davis KL, Decker JM, Wycuff D, Harris L, Hawkins N, et al: Profiling the specificity of neutralizing antibodies in a large panel of plasmas from patients chronically infected with human immunodeficiency virus type 1 subtypes B and C. J Virol 2008, 82:11651-11668.

17. Brown BK, Wieczorek L, Kijak G, Lombardi K, Currier J, Wesberry M, Kappes JC, Ngauy $V$, Marovich M, Michael N, et al: The role of natural killer (NK) 
cells and NK cell receptor polymorphisms in the assessment of HIV-1 neutralization. PLOS ONE 2012, 7:e29454.

18. Carrington M, Alter G: Innate Immune Control of HIV. Cold Spring Harb Perspect Med 2012, 2:a007070

19. Nishimura Y, Igarashi T, Haigwood N, Sadjadpour R, Plishka RJ, Buckler-White A, Shibata R, Martin MA: Determination of a statistically valid neutralization titer in plasma that confers protection against simian-human immunodeficiency virus challenge following passive transfer of high-titered neutralizing antibodies. J Virol 2002, 76:2123-2130.

20. Nishimura Y, Igarashi T, Haigwood NL, Sadjadpour R, Donau OK, Buckler C, Plishka RJ, Buckler-White A, Martin MA: Transfer of neutralizing IgG to macaques $6 \mathrm{~h}$ but not $24 \mathrm{~h}$ after SHIV infection confers sterilizing protection: implications for HIV-1 vaccine development. Proc Natl Acad SCi USA 2003, 100:15131-15136.

21. Forthal DN, Gabriel EE, Wang A, Landucci G, Phan TB: Association of Fcgamma receptor Illa genotype with the rate of HIV infection after gp120 vaccination. Blood 2012, 120:2836-2842.

22. Staprans SI, Barry AP, Silvestri G, Safrit JT, Kozyr N, Sumpter B, Nguyen H, McClure H, Montefiori D, Cohen Jl, Feinberg MB: Enhanced SIV replication and accelerated progression to AIDS in macaques primed to mount a CD4 T cell response to the SIV envelope protein. Proc Natl Acad Sci USA 2004, 101:13026-13031.

23. Hosie MJ, Osborne R, Reid G, Neil JC, Jarrett O: Enhancement after feline immunodeficiency virus vaccination. Vet Immunol Immunopathol 1992, 35:191-197.

24. Siebelink KH, Tijhaar E, Huisman RC, Huisman W, de Ronde A, Darby IH, Francis MJ, Rimmelzwaan GF, Osterhaus AD: Enhancement of feline immunodeficiency virus infection after immunization with envelope glycoprotein subunit vaccines. J Virol 1995, 69:3704-3711.

25. Richardson J, Moraillon A, Baud S, Cuisinier AM, Sonigo P, Pancino G Enhancement of feline immunodeficiency virus (FIV) infection after DNA vaccination with the FIV envelope. J Virol 1997, 71:9640-9649.

26. Hammond SA, Raabe ML, Issel CJ, Montelaro RC: Evaluation of antibody parameters as potential correlates of protection or enhancement by experimental vaccines to equine infectious anemia virus. Virology 1999, 262:416-430.

27. Halstead SB: Pathogenesis of dengue: challenges to molecular biology. Science 1988, 239:476-481.

28. Dejnirattisai $W$, Jumnainsong $A$, Onsirisakul N, Fitton $P$, Vasanawathana $S$, Limpitikul W, Puttikhunt C, Edwards C, Duangchinda T, Supasa S, et al: Cross-reacting antibodies enhance dengue virus infection in humans. Science 2010, 328:745-748.

29. Wallace MJ, Smith DW, Broom AK, Mackenzie JS, Hall RA, Shellam GR, McMinn PC: Antibody-dependent enhancement of Murray Valley encephalitis virus virulence in mice. J Gen Virol 2003, 84:1723-1728.

30. Ponnuraj EM, Springer J, Hayward AR, Wilson H, Simoes EA: Antibodydependent enhancement, a possible mechanism in augmented pulmonary disease of respiratory syncytial virus in the Bonnet monkey model. J Infect Dis 2003, 187:1257-1263.

31. Takada A, Feldmann H, Ksiazek TG, Kawaoka Y: Antibody-dependent enhancement of Ebola virus infection. J Virol 2003, 77:7539-7544.

32. Iankov ID, Pandey M, Harvey M, Griesmann GE, Federspiel MJ, Russell SJ: Immunoglobulin $\mathrm{G}$ antibody-mediated enhancement of measles virus infection can bypass the protective antiviral immune response. J Virol 2006, 80:8530-8540

33. Onyango-Makumbi C, Omer SB, Mubiru M, Moulton LH, Nakabiito C, Musoke P, Mmiro F, Zwerski S, Wigzell H, Falksveden L, et al: Safety and efficacy of HIV hyper immune globulin for prevention of mother-to-child HIV transmission in HIV-1-infected pregnant women and their infants in Kampala, Uganda (HIVIGLOB/NVP STUDY). J Acquir Immune Defic Syndr 2011, 58:399-407.

34. Burton DR, Hessell AJ, Keele BF, Klasse PJ, Ketas TA, Moldt B, Dunlop DC, Poignard P, Doyle LA, Cavacini L, et al: Limited or no protection by weakly or non-neutralizing antibodies against vaginal SHIV challenge of macaques compared with a strongly neutralizing antibody. Proc Natl Acad Sci USA 2011, 108:11181-11186.

35. Takeda A, Ennis FA: FcR-mediated enhancement of HIV-1 infection by antibody. AIDS Res Hum Retroviruses 1990, 6:999-1004.

36. Robinson WE Jr, Montefiori DC, Mitchell WM: Antibody-dependent enhancement of human immunodeficiency virus type 1 infection. Lancet 1988, 1:790-794
37. Willey S, Aasa-Chapman MM, O'Farrell S, Pellegrino P, Williams I, Weiss RA, Neil SJ: Extensive complement-dependent enhancement of HIV-1 by autologous non-neutralising antibodies at early stages of infection. Retrovirology 2011, 8:16.

38. Stoiber H, Soederholm A, Wilflingseder D, Gusenbauer S, Hildgartner A, Dierich MP: Complement and antibodies: a dangerous liaison in HIV infection? Vaccine 2008, 26(Suppl 8):179-185.

39. $\mathrm{NIH}$ discontinues immunizations in HIV vaccine study. http://www.niaid. nih.gov/news/newsreleases/2013/Pages/HVTN505April2013.aspx.

40. Thali M, Moore JP, Furman C, Charles M, Ho DD, Robinson J, Sodroski J: Characterization of conserved human immunodeficiency virus type 1 gp120 neutralization epitopes exposed upon gp120-CD4 binding. J Virol 1993, 67:3978-3988.

41. Montefiori DC: Evaluating neutralizing antibodies against HIV, SIV, and SHIV in luciferase reporter gene assays. Curr Protoc Immunol 2005, 12(12):11.

42. Watkins JD, Siddappa NB, Lakhashe SK, Humbert M, Sholukh A, Hemashettar G, Wong YL, Yoon JK, Wang W, Novembre FJ, et al: An anti-HIV-1 V3 loop antibody fully protects cross-clade and elicits T-cell immunity in macaques mucosally challenged with an R5 clade C SHIV. PLOS ONE 2011, 6:e18207.

43. Hessell AJ, Hangartner L, Hunter M, Havenith CE, Beurskens FJ, Bakker JM, Lanigan CM, Landucci G, Forthal DN, Parren PW, et al: Fc receptor but not complement binding is important in antibody protection against HIV. Nature 2007, 449:101-104.

44. Gomez-Roman VR, Florese RH, Patterson LJ, Peng B, Venzon D, Aldrich K Robert-Guroff M: A simplified method for the rapid fluorometric assessment of antibody-dependent cell-mediated cytotoxicity. J Immunol Methods 2006, 308:53-67.

45. Edmonds TG, Ding H, Yuan X, Wei Q, Smith KS, Conway JA, Wieczorek L Brown B, Polonis V, West JT, et al: Replication competent molecular clones of HIV-1 expressing Renilla luciferase facilitate the analysis of antibody inhibition in PBMC. Virology 2010, 408:1-13.

46. Keele BF, Li H, Learn GH, Hraber P, Giorgi EE, Grayson T, Sun C, Chen Y, Yeh WW, Letvin NL, et al: Low-dose rectal inoculation of rhesus macaques by SIVsmE660 or SIVmac251 recapitulates human mucosal infection by HIV-1. J Exp Med 2009, 206:1117-1134.

47. Salazar-Gonzalez JF, Salazar MG, Keele BF, Learn GH, Giorgi EE, Li H, Decker JM, Wang S, Baalwa J, Kraus MH, et al: Genetic identity, biological phenotype, and evolutionary pathways of transmitted/founder viruses in acute and early HIV-1 infection. J Exp Med 2009, 206:1273-1289.

doi:10.1186/1742-4690-11-8

Cite this article as: Sholukh et al:: Passive immunization of macaques with polyclonal anti-SHIV IgG against a heterologous tier 2 SHIV: outcome depends on lgG dose. Retrovirology 2014 11:8.

\section{Submit your next manuscript to BioMed Central and take full advantage of:}

- Convenient online submission

- Thorough peer review

- No space constraints or color figure charges

- Immediate publication on acceptance

- Inclusion in PubMed, CAS, Scopus and Google Scholar

- Research which is freely available for redistribution 